\title{
Social Network System For Accounting Students
}

\author{
Nujmatul Laily ${ }^{1}$, Eka Ananta Sidharta ${ }^{2}$ \\ \{nujmatul.laily.fe@um.ac.id ${ }^{1}$ \} \\ ${ }^{1,2}$ Universitas Negeri Malang, Malang, Indonesia
}

\begin{abstract}
This study aims to develop edmodo-based learning media to improve the quality of Accounting study in Higher Education. Edmodo is a social network designed specifically for learning where it enables the active interaction between lecturers and students without being limited by time and place. The reason for the development of edmodo based learning media is because of its ease of use (user friendly) than Moodle, more familiar among students because edmodo is almost the same as facebook.. This research is categorized as research and development using ADDIE design model which consists of several stages: analyze, design, develop, implementation and evaluate. The result indicate that edmodo-based learning media can improve student's learning motivation.
\end{abstract}

Keywords: social networks, accounting students, learning media

\section{Introduction}

Learning problems that occur in the universities have always been an interesting issue to study because the quality of learning, especially in the universities is one indicator of the quality of a nation. High quality education can be seen from the ability of graduates in competing in the world of work, mastery of knowledge, science and technology. In other words, college graduates are not only required to master science but also are expected to master and utilize information technology. This is supported by Bawaneh (2011) who said that the use of information technology becomes an integral part of the teaching and learning process in the universities. In fact, not all college graduates have the ability to develop and utilize the advancement of information technology.

Competence of graduates for the mastery of information technology is also contained in the KKNI where the undergraduate program is at the sixth level of qualification and the level of work ability required at this level ie the undergraduate must be able to apply, study, design, utilize science and technology and solve problems. Based on the KKNI, it appears that one of the competencies of college graduates is the ability to utilize science and technology.

Therefore, learning in higher education should be directed to ICT-based learning so that the learning process that occurs is student centered to foster an active learning atmosphere and responsive. But the problem is, how to create ICT-based learning so that students can participate actively?. The answer to this problem is the use of ICT-based learning media in learning, known as e-learning.

E-learning is a deliberate use of information and communication technology networks in the learning and teaching process. E-learning is also known as online learning or web based learning. With e-learning allows intensive interaction between faculty and students through the computer (internet) in each place without having to face to face directly. According to Sindu 
(2013) e-learning atmosphere can accommodate learners play a more active role in learning, learners make designing and looking for material with their own efforts. The result of e-learning implementation for the students of Accounting Study at Universitas Negeri Malang shows that e-learning can increase learning and discussion activities so that it can increase the quality of students' learning outcomes (PJJ Accounting Team, 2012). In addition to UM, one of the universities that uses e-learning is the Universitas Terbuka which is being aggressively promoting Distance Education (PJJ). E-learning is the main medium for conducting Distance Education (PJJ). With e-learning allows lecturers and students do not have to always face to face in the classroom but can interact in the virtual world (virtual classroom) without putting aside the purpose of learning.

The tendency to develop e-learning as one of the alternative learning in the universities, especially in accounting courses is increasing in line with the development in the field of communication and information technology. However, observation results at one public and private universities in East Java found that the utilization of e-learning is still very low. Based on observations and interviews with several lecturers, the low utilization of $7 e$-learning is caused by several factors; first, the inability of lecturers to utilize e-learning version of Moodle provided by universities because of its difficult use so that lecturers prefer to use conventional method (lecture and explain on board / power point) to deliver the material. This resulted in the low interest of students to follow the lectures, the learning process was boring and the intensity of students in touch with low technology because students only listen and record explanations from lecturers. Second, the characteristics of the course also contribute to the low use of elearning by lecturers. Accounting courses are dominated by numbers so some lecturers assume that the use of e-learning is less suitable for Accounting courses so lecturers prefer to explain by lecturing in front of the class and demonstrating sample on the board. Third, students are less enthusiastic about using e-learning moodle version with various reasons that lecturers do not introduce and do not require students to use e-laerning, not practical, hard to understand, and the view is less interesting. These three factors lead to low access to moodle e-learning by Accounting lecturers and students.

Based on these problems, this research will develop a user friendly learning media especially for lecturers and accounting students by developing edmodo based learning media to improve the quality of Accounting learning. Edmodo is one of the most popular social networks since 2008. Edmodo is also known as facebook for education and now connects over 49 million billion teachers / lecturers and students in the world. Edmodo is almost the same as facebook but in edmodo a lecturer has more control, free and safe application for students and teachers to interact and collaborate. The use of edmodo as a learning medium is easier compared to moodle so that lecturers and students will not have difficulty in using edmodo as a very interesting learning media because lecturers and students can interact in virtual classroom without being limited by time and place. In addition, this media can also be applied to accounting courses that can be designed in such a way that students will not find it difficult in understanding the material Accounting.

Previous research has also been conducted to determine the effect of technology utilization in teaching and learning process of student (Beglau, 2005; Phye \& O'Connell, 2007; Martin, Strother \& Reitzes, 2009; Shapley, Sheehan, Maloney \& Caranikas-Walker, 2010). The results of this study show that the use of edmodo in learning has a significant influence on the improvement of student learning outcomes (Suriadhi, et al., 2014, Basori, 2013). However, the development of edmodo-based learning media that has been done by previous researchers is mostly done on non-exact subjects. Based on the problems that have been described previously, this research will offer solutions by developing edmodo based learning media that is relatively 
easy to use both by lecturers and students with the aim to improve the quality of accounting learning in universities.

\section{Research Methodology}

\subsection{Edmodo-Based Learning Media}

Learning media has a very important role in supporting teaching and learning activities. Heinich, et al (1982) defines instructional media as "the term refer to anything that carries information between a source and a receiver". This indicates that the media is everything that can convey information from information sources to the recipient between lecturers and students in teaching and learning process where the lecturer as a source of information and students as recipients of information.

Edmodo is one of the most popular social media since 2008. Edmodo is almost the same as facebook but in edmodo a teacher / lecturer has more control, free and safe application for student. Edmodo is a social network that can be accessed by teachers, students and parents of students. By using edmodo, lecturers can enter teaching materials, make assignments, make announcements, take notes, conduct quizzes and make judgments.

Edmodo as a learning media allegedly can affect the quality of student learning. Rismayanti (2012) says that edmodo allows students to interact with faculty and other students in an academic setting. Furthermore, this medium teaches students to manage and take responsibility in their learning activities.

\subsection{The Differences Between Edmodo and Moodle}

Moodle e-learning version is widely used in various institutions, especially higher education. However, there have been many complaints about the use of moodle because of its complex and high cost usage so that many are turning to develop edmodo based learning media with some considerations.

The following shows the difference between edmodo and moodle versions that the use of edmodo easier than moodle because some things like edmodo does not need to be installed, lecturers and students can access at www.edmodo.com for free, based social networking where students and lecturers are very familiar with social networking like facebook, and do not need to set various things just use it all the features available. With this ease then edmodo-based learning media deserve to be developed as a medium of learning accounting.

\section{Methodology}

This research is categorized as research and development because the purpose of this research is to produce a product in the form of edmodo based learning media to improve Accounting learning. This research uses ADDIE design model. Selection of this model is based on the consideration that this model is easy to understand and developed systematically in designing instructional media in accordance with the characteristics and needs of the user. The stages of development based on this ADDIE model are analyze, design, develop, implementation and evaluation. The population of research is public and private universities in Malang which have Accounting department. Sampling method using purposive sampling where the sample research will be represented by two state universities and two private universities in 
the city of Malang. This is done to find out how the learning process, learning media, teaching methods, and learning facilities conducted in public and private universities in the city of Malang. The data used in this study is primary data directly obtained from the respondents. Data collection techniques used were questionnaires, observations and interviews. Questionnaires are used to determine the specifications of instructional media needed and desired by lecturers and students. In-depth interviews were conducted to students and lecturers of accounting course managers to find out more in depth about instructional media used in accounting courses and teaching methods of lecturers. Direct observation is used to know the phenomenon that exists when the learning is ongoing so that the observation data is expected to deepen the information not obtained by the questionnaire and interview techniques. Data analysis technique used in this research is quantitative and qualitative data analysis

\section{Result and Discussion}

This research uses ADDIE research design model. Selection of this model is based on the consideration that this model is easy to understand and developed systematically in designing instructional media in accordance with the characteristics and needs of the user. The stages of development based on this ADDIE model are analyze, design, develop, implementation and evaluation. In this stage of analysis, the needs analysis is based on the need for instructional media, subject characteristics, presentation of materials, and the readiness of facilities and infrastructure. To find out the need for instructional media, the researcher distributed the questionnaire to the students where the majority of students revealed that during this learning still focuses on lecturers, lecture in class accompanied by PPT is still a favorite for most of the accounting lecturers, only a few have introduced and used media other than PPT and whiteboard. Interviews also found that students are keen to learn not only in class, learning can be done with fun and ICT-based learning so that activities such as task assignment, task gathering, discussion, quiz, mid and final test can be based on ICT.

Characteristics of the course and presentation of the material also become one of consideration factors for a lecturer in using learning media. In general, subjects with larger portions prefer to use conventional methods by explaining on the board. The reason, accounting subject is more difficult and takes longer time when using ICT-based media such as E-learning especially for mid test and final test so that the course will be developed using e-learning only for auditing and computer accounting subject.

This auditing course will provide students insight into the basic principles and concepts of audit, ISA-based auditing, professional standards of public accountants and professional codes of ethics, public accountant's legal responsibilities, accountant reports, audit planning and audit testing types, audit evidence, working paper, internal control, materiality, risk assessment, audit program and comprehensive audit plan. After completing this course, the students are expected to be able to understand the basic concept of audit and able to make audit plan. While the student accounting computer course learn about the preparation of initial data company into the program MYOB Accounting v. 18 consisting of: activities of setting the account chart, setting the tax code, linked accounts, making cards accounts receivable, trade payable, and stock. Then the students are asked to fill the beginning balance of each account ledger book along with auxiliary books, entry transactions to produce financial reports. After taking this course students are expected to be able to make financial reports service company, trade and manufacturing by using MYOB software. 
The readiness of facilities and infrastructure is also very important in developing learning media. Learning media based on e-learning requires a means of computer and internet network to access and use e-learning. The questionnaire results show that all students have smartphones that enable students to access e-learning using their mobile phones. So that based on the analysis of the needs of users of instructional media can be concluded that the students need a fun medium, which can be accessed wherever and whenever and the media that allows assignment tasks, tasks, quiz, mid test and final test done online so that learning is really done paperless. Media that fits perfectly with the user's needs is edmodo based e-learning media that can be accessed for free by the user either using computer or smartphone. The purpose of the use of this medium of learning can be directed into student centered learning.

With the findings, the recommendation of instructional media in accordance with the needs of the field are as follows: learning media that can be accessed anytime and anywhere, learning media that lets students do not have to meet face to face with the lecturers in the classroom, learning media that allows interaction between students and lecturers and students with students virtually, the learning media that enables the granting and collection of tasks is paperless, learning media that allows online evaluation whether it is a quiz, mid test or final test , learning media based on e-learning that can be accessed for free and learning media that can be accessed using a smartphone.

The next step is the design stage, this stage is the stage of learning media design after the needs analysis. The design includes the design of media that will be developed, the preparation of materials, questions and answers, video tutorials and other things that if necessary.

\subsection{Media design}

Learning media used in this study using edmodo-based learning media that can be accessed for free at www.edmodo.com. This media selection consideration is based on its ease of use compared to other e-learning such as Moodle which is more complicated and requires more expensive cost in its development. Researchers will do a little manipulation of this learning media by adding video tutorials, links to youtube and other additions.

\subsection{Preparation of material}

The material that will be developed and used in edmodo based learning media is focused only on the auditing and accounting computer courses. The auditing material developed is focused on the design and planning of audit, internal control, etc. while the material for accounting computer course focuses on preparing financial statements of service and trading companies using MYOB software. For accounting computer course will only be developed video-based material tutorial while for the auditing course will be developed teaching materials, video tutorials and evaluation tool for mid test and final test. In addition, researchers also developed edmodo based teaching materials that can be used by students in learning as well as a guide book in learning edmodo.

\subsection{Preparation of evaluation tools / answers and answers}

Problems and answers that will be developed in this research is only focus for computer accounting and auditing courses. Problem for accounting computer course that will be developed in the case of service company cycle and trading company. for auditing course that will be developed only focus on certain subject, will also be developed about mid test and final test that can be done directly in edmodo and its value can be immediately known by the students.

\subsection{Making video tutorial}


Video tutorial that will be developed that is for accounting computer course with subject matter accounting cycle of service company and trading company.

In the develop stage, researchers create and develop edmodo-based learning media. Edmodo is a school-based environment based school environment. Developed by Nicolas Borg and Jeff O'Hara, Edmodo is intended for use for teachers, students and parents. Edmodo almost the same as facebook only just used specifically for teaching and learning activities. Edmodo can be accessed for free at www.edmodo.com. But in this study, researchers will do the development by adding video tutorials, links to youtube and other additions.

\subsection{Validation of Media Experts and Material Experts}

After the development of learning media then the next stage is the expert validation. Validation of media experts and material experts is used to provide media-related suggestions as well as developed material.

\subsection{Material Expert Validation}

Validation of material experts aims to determine the feasibility of the material developed and uploaded in edmodo-based learning media. The first validator is one accounting lecturer at the University of Kanjuruhan Malang to validate the material content. The goal is to ensure that the material created in edmodo-based learning media has been in accordance with competence in the course of Computer Accounting and presented material is also valid. In this case, the researcher gives an instrument to the material expert to assess the material worthiness.

Overall material validation results indicate that the material presented in edmodo based learning media is in accordance with basic competence, the material presented is systematic and easy to understand, and the instructions on edmodo problem is very clear. However, the problem or the given case is deemed not to have the level of complexity tailored to the basic competencies so that researchers will revise and develop new evaluation questions that have difficulty level according to basic competencies.

\subsection{Media Expert Validation}

Validation of media experts aims to validate the media that has been developed. The second validator is a lecturer in Jember university to validate edmodo based learning media. The goal is to provide advice and feedback regarding the feasibility of developed learning media.

\section{Conclusion}

This research aims to develop edmodo-based learning media. The result of requirement analysis shows that the students need instructional media with the following specifications: A fun learning media, learning media that can be accessed anytime and anywhere, Learning media that allows students not face to face directly with lecturers in the classroom, Media learning that allows interaction between students and lecturers and students with virtual students, learning media that enables the giving and gathering of tudas is paperless, learning media that allows online evaluation whether it is quiz, mid test or final test, e- learning that can be accessed for free, learning media that can be accessed using a smartphone. Based on the analysis of the needs of the developed edmodo-based learning media that suits the needs of the user. Edmodo-based learning media has also been validated by material and media experts. 


\section{REFERENCES}

[1] Asfyra dan Kesumawati. 2010. Social Network Sebagai Pendukung Pembelajaran. Artikel tidak dipublikasikan

[2] Ayati dan santihosi. 2013. E-Learning Dengan Aplikasi Edmodo. Artikel tidak dipublikasikan.

[3] Basori. 2013. Pemanfaatan Social Learning Network "Edmodo" Dalam Membantu Perkuliahan Teori Bodi Otomotif Di Prodi Ptm Jptk Fkip Uns. JIPTEK, Vol. VI No.2.

[4] Bawaneh. S.S. 2011. Informtaion Technologi, Accounting Information System and Their Effect on the Quality of Accounting Education in The University: An Empirical Research Applied on Jordanian Financial Institution. Interdiciplinary Journal on Contemporary Research on Business. 3 (2)

[5] Beglau, M.M. 2005. Can Technology Narrow The Black White Achievement Gap? T.H.E. Journal. 32 (12)

[6] Challoo, L.,Green, M \& G. Maxwell. 2010. Attitudinal Factors Contributing to Teacher Stage of Adoption of Technology in Rural South Texas: A Path Analysis. Journal of Technology Integration in The Classroom, 3 (1)

[7] Heinich, Robert, Michael Molenda, James D. Russel, (1982) Instructional Media:and the New Technology of Instruction, New York: Jonh Wily and Sons

[8] Rismayanti, Anti. 2012. Mengenal lebih dekat edmodo sebagai media e-learning dan kolaborasi. Artikel tidak dipublikasikan

[9] Robert's, F.D, Kelley, C.L \& B.D. Medlin. 2007. Factors Influencing Accounting Faculty Member's Decision to Adopt Technology in The Classroom. College Student Journal, 41 (2)

[10] Shapley, K., et al. 2010. Effect on Technology Immersion on Teacher Growth in Technology Competency, Ideologi \& Practises. Journal of educational Computing Research. 42 (1)

[11] Sindu, I.G. Partha, dkk. 2013. "Pengaruh Model E-Learning Berbasis Masalah dan Motivasi Belajar terhadap Hasil Belajar KKPI Siswa Kelas X di SMK Negeri 2 Singaraja". E-journal Program Pascasarjana Universitas Pendidikan Ganesha, Volume 3, (hlm. 1-10).

[12]Suriadhi, dkk. 2014. Pengembangan E-Learning Berbasis Edmodo Pada Mata Pelajaran Ipa Kelas Viii Di Smp Negeri 2 Singaraja. Journal Edutech Universitas Pendidikan Ganesha

[13] Tim PJJ Akuntansi, 2012. Pengembangan Model Pembelajaran Jarak Jauh (PJJ) Berbasis E-Learning Versi Moodle pada Prodi S-1 Pendidikan Akuntansi Universitas Negeri Malang 